\title{
THE ROLE OF REGULATORY AUTHORITIES IN THE PROMOTION OF COMPETITION IN THE PUBLIC UTILITIES SECTOR
}

Purpose of the paper is to provide the legal analysis of correlation of regulation and competition to determine the role of regulatory authorities in the promotion of competition in the public utilities sector.

Methods. The analysis of notions of the relations between regulation and competition, as well as form of competition in the public utilities sector is based on the formal logical and deductive methods.

Results. The first part is focused on the analysis of different approaches to the correlation of regulation and competition in network industries. Different notions of the relations between regulation and competition are considered, namely such notions as deregulation, re-regulation, regulation-of-competition, regulation-for-competition and meta-regulation. The second part highlights forms of competition in the public utilities sector, including separation of vertically integrated monopolies and yardstick competition. The author refers to several approaches to restructuring of utilities and their regulation and concludes that yardstick competition facilitated by regulatory authorities has a great potential in the public utilities sector. The third part deals with the role of regulatory authorities in promotion of competitive mechanisms in the public utilities sector of Ukraine. Based on the analysis of the legal framework the author comes to the conclusion that Public Utilities Regulator in Ukraine may promote competition through performing monitoring over competitive segments of the mar$k e t$, regulation of access to networks and incentive-based regulation that includes different forms of yardstick competition.

Conclusions. First, regulation and competition are not exclusive, but complementary and non-competing mechanisms that can co-exist within one market. Second, introduction of direct and indirect forms of competition in the public utilities sector expands a toolbox of the regulatory authorities by empowering regulators to perform monitoring over potentially competitive markets, access regulation and incentive-based regulation. Third, the Energy and public utilities regulator in Ukraine is responsible for promotion of competition that expands its functions far beyond core regulation ones; striking a careful balance between core regulatory and monitoring functions gains extraordinary importance.

Key words: regulation, competition, regulatory authorities, network industries, public utilities sector. 


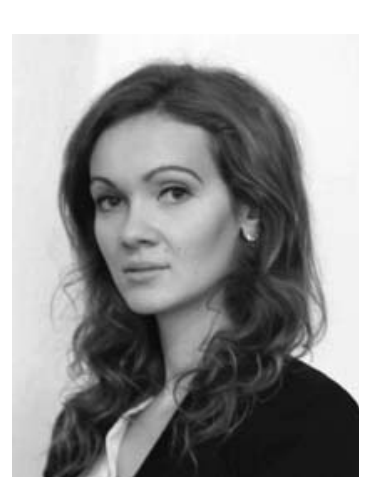

Alona Kazantseva, Clean Energy Leadership Institute Fellow,

Washington D.C.

aokazantseva@gmail.com orcid.org/0000-0003-4938-6701

\section{Introduction}

Over the last decades, Ukraine has faced a number of challenges in the public utilities sector, including technical, financial and environmental ones. As of today, the lifetime of infrastructure facilities considerably exceeds the mark of 25 to 30 years, meaning that most facilities are in operation from the Soviet Union times. Improper technical condition of the infrastructure and operation of outdated and worn-out equipment lead to low energy efficiency, significant losses in the network systems and environmental pollution (Kovalko \& Kazantseva, 2015).

This situation caused unnecessary costs, economically unjustified tariffs, which during a long period of time have not covered expenses for production and supply of public utility services, as well as inefficient institutional structures that include low payment discipline of consumers (Institute for Social and Economic Strategies, 2012). The situation worsened because public authorities, regulators and utilities mainly focus their activities on production and operation of systems instead of focusing on consumers' needs. The orientation on production gives utilities little incentive to improve the quality of their operations and provide consumers a reliable and not expensive service. Further, the poor governance and significant influence of corruption create obstacles for investment and deepen the crisis in the industries that belong to the public utilities sector.

In the theory and practice of state regulation it is determined that in order to address the key challenges of public utilities, the choice between two paths should be made: regulation or competition. Based on this approach, regulation and competition are two separate mechanisms that cannot co-exist within the market. However, the relations between regulation and competition have been significantly changed. Recent case studies from the public utilities sector show us that today there is no strict distinction between regulation and competition. Regulation frequently plays a promotional role by empowering regulatory authorities to promote competition in the public utilities sector. The promotion of completion and control over its development is a core function of competition authorities. That is why the exploring of new notions of correlation of regulation and competition to determine the role of regulatory authorities in the promotion of competition gains a significance importance.

Therefore, the aim of this paper is to provide the legal analysis of the correlation of regulation and competition, and 
determine the role of regulatory authorities in the promotion of competition in the public utilities sector. The tasks of the paper are as following: to analyze the scientific approaches to the correlation of regulation and competition in network industries, to explore the forms of competition in the public utilities sector, to determine role of regulatory authorities in the promotion of competition in the public utilities sector.

\section{Correlation of regulation and competition in network industries}

For many decades, the concept of natural monopoly was applied to the network industries such as telecommunications, electricity, gas, postal services, transport, etc. Technological changes and liberalization of network industries removed the barriers and opened the markets for new entrants. It became apparent that the state regulation mechanism was artificially "imposed" on competitive industries. In this context P. Westin and F. Lagergren emphasize that "opening of markets in network sectors illustrates a shift in common opinion about the nature of these industries". According to the scholars, "where once regulated or government owned monopolies dominated because of the belief that most utilities were "natural monopolies", there is now a growing consensus that competition can perform a broader and more effective role (Westin \& Lagergren, 2002).

Despite of competitive nature of network industries, regulatory authorities did not question the assertion that regulation was required when "market failures" occurred. According to R.A. Posner, competition is not a viable regulatory mechanism under conditions of natural monopoly. From his point of view, "if such a market contains more than one firm, either the firms will quickly shake down to one through mergers or failures, or production will continue to consume more resources than necessary. In the first case, competition is short-lived and in the second, it produces inefficient results" (Posner, 1968).

Other scholars also supported this approach and provided empirical evidence that regulation and competition are two separate mechanisms that cannot co-exist. (Stigler, 1975). After all, if markets are competitive, there is no need to regulate them. However, in case when competition is not feasible or effective, the state should substitute competitive mechanism by regulatory one. Although this aspect of the correlation of regulation and competition is still a part of on-going discussion, it does not reflect the current trends in the development of network industries. Technological changes, liberalization, and regulatory reforms underlined the need to develop new approaches that would capture modern correlation of regulation and competition.

J. Jordana and D. Levi-Faur describe five notions that are used in the literature to capture the relations between state regulation and competition. These notions include deregulation, re-regulation, regulation of competition, regulation for competition and meta-regulation (Jordana \& Levi-Faur, 2004).

The process of deregulation in network industries started in 1970ths in the United States as a response to the need to remove or reduce a comprehensive control over particular industries in order to ensure competition (Posner, 2011). However, most of network industries are still in the midst of transition that involve restructuring, deregulation of major industry segments, and application of new regulatory mechanisms to those segments that continue to be regulated (Joskow, 2005). Regarding these industries, it is fair to say that the regulation was changed rather than diminished. 
The notion of re-regulation is frequently used in the context of liberalization process and regulatory reforms in the meaning of transition to new regulatory approaches and tools. We agree with J. Jordana and D. Levi-Faur that nowadays the relations between regulation and competition significantly changed, the regulatory toolbox was expanded, and today it contains new tools and techniques. We also share their point of view that the notion of re-regulation does not provide a clear asnwer to the question on the nature and objectives of new regulation, as well as a full description of new regulatory tools and techniques that are a part of the re-regulation mechanism (Jordana \& Levi-Faur, 2004).

Besides deregulation and re-regulation, J. Jordana and D. Levi-Faur also explore such forms as regulation-of-competition, regulation-for-competition and meta-regulation. The scholars believe that "the notions of regulation-of-competition and regulation-for-competition allow to promote competition via administrative control". These notions "differ in the degree of intervantion by state authorities and in the capacities of the state to monitor and enforce competition". According to J. Jordana and D. Levi-Faur, "in regulation-of-competition national competition authorities have economy-wide responsibilities that allow them less influence the market actors; on the contrast, in the regulation-for-competition regulatory authorities have narrow sector-specific responsibilities that give them much more influence over market actors and allow be involved in market design and market control to an unprecedented extent". J. Jordana and D. Levi-Faur point out that meta-regulation occurs when the process of regulation itself becomes regulated. As an example they provide institutionalization of internal mechanisms of self-regulation that correspond with the legal requirements of competition law in general and the regulatory regime in particular (Jordana \& Levi-Faur, 2004).

The distinction of regulation-of-competition, regulation-for-competition and meta-regulation as separate forms can be argued. The significance of changes in the correlation of regulation and competition, and extension of regulatory tools is evident and thus beyond any doubts. However, we believe that the notions of regulation-of-competition and regulation-for-competition shall be captured by the notion of re-regulation. As far as the main purpose of re-regulation is to establish new regulatory settings, it also can includes the key features of regulation-of-competition and regulation-for-competition that aim at promoting competition via administrative control.

P. Crampton provides the most structured approach to the correlation of regulation and competition. The scholar pays attention to the fact that "competition and regulation have the same ultimate goals, namely to prevent the illegitimate acquisition and exercise the market power and to facilitate the efficient allocation of resources". From his point of view, "where free and unrestricted competition is unlikely to produce this result, it is generally recognized that some sort of regulation is appropriate, either as a full substitute of competition, as means for establishing a sustainable framework, within which effective competition can take place, or as means of "holding a fort" until the anticipated arrival of competition" (Crampton, 2002). Therefore, nowadays regulation plays both roles - substitutional and "promotional". It means that regulation substitutes competition, when it is required, and regulation promotes competition by establishing a framework for it and by facilitating a transition from regulation to competition. 
Based on this, a few conclusions can be drawn. A primary approach to the correlation of regulation and competition was that these policies could not co-exist within the market. Regulatory and competitive mechanisms could not be applied to the market at the same time. In each particular case there was a need to determine, whether the competition was feasible or not. If it was not feasible, then competition should be substituted by regulation. The distinction between regulation and competition was clear: market could be either competitive, or regulated. However, over the decades, this strict distinction between regulation and competition erased and new forms of their correlation appeared. For effective functioning of network industries, it is crucial to use both mechanisms. That is why regulation and competition are complementary and non-competing mechanisms.

\section{The forms of competition in the public utilities sector}

The historical model of network industries was premised on the assumption that some markets including their natural monopoly segments and competitive ones "were best served - and served best - when structured as vertically integrated monopolies" (Kessides, 2004). It was a standard practice "to lump the different activities together, treat them as monopolies normally to be supplied by a single vertically integrated firm, and then to regulate the firm as a single entity on an end-to-end basis" (Baldwin, Cave \& Lodge, 2012). However, in recent years the approach to utility regulation was changed. Network industries are not treated as monolithic natural monopolies. Instead, they are divided into different activities that allow applying state regulation and competition mechanisms within a single market.

This modern approach offers to separate vertically integrated monopolies. The simple version of this concept distinguishes "the network, considered to be a natural monopoly in the traditional sense, and downstream markets open to the introduction of effective competition if non-discriminatory third party access to the networks is granted to all competitors" (Kirchner, 2006). In the other words, transmission distribution are with a few exceptions regulated monopolistic activities, while generation and supply - competitive ones.

In practice, the separation of the natural monopoly from the competitive segments of the market can be achieved by breaking down of vertically integrated monopolies and unbundling of their activities. D. Newbery in his papers describes two broad approaches to restructuring of utilities.

The radical approach captures the vertical ownership separation of monopoly segments (transportation and distribution) from the structurally competitive segments (upstream production and downstream supply) (Newbery, 2000). In this case, regulatory authorities shall be responsible for regulation of monopoly segments of the market, while competition authorities shall monitor its competitive segments. As pointed out in the World Bank Policy Research Report, many developing and transition economies still lack good competition policies; some have not even implemented the basic elements of competition law and have made uneven progress in establishing strong competition authorities (Kessides, 2004). Given this, the role of regulatory authorities increases: they continue regulating the monopoly segments of the market and additionally perform monitoring function over the development of competition until appropriate policy and relevant competitive authorities are created. 
The second approach described by D. Newbery allows the owner of the network to carry out integrated operations on the condition that it ensures fair and equal access to the network facilities to the third parties (Newbery, 2000). In this case, regulation of the access to the network infrastructure (access regulation) gains extraordinary importance, as regulation enables competition on the downstream markets. Within this approach, regulatory authorities promote competition via regulatory mechanism and thus combine core regulatory functions with the functions of competitive authorities.

The technology used by district heating, water supply and sewage, as well as solid waste management sector makes long distance transmission and supply inefficient. Moreover, unlike other network industries, the public utilities sector has relatively small size of markets that does not allow many entities to operate and compete. Therefore, separation of monopoly from competitive segments of the market is not always a feasible solution for the public utilities sector. Despite of technology and market size constraints, the process of liberalization and promotion of competition in the public utilities sector is still possible. In practice, some forms of indirect competition may occur in these markets. One of the examples of indirect competition facilitated by regulatory authorities is yardstick competition or benchmarking.

Yardstick competition or benchmarking aims at ensuring competition between utilities according to certain indicators (benchmarking). The universal benchmarking model was introduced by M. Spendolini, who defines benchmarking as "a permanent systematic process for assessing goods, services and work processes of organizations, by identifying best practices for the purpose of improvement of activities of these organizations" (Spendolini, 1992).

Benchmarking process in the public utilities sector can be described as following. The regulator makes decision on indicators to compare the activities of utilities within the formed group. The regulator also determines the conditions and efficiency of the operation of each utility, defines the performance indicators for the group, and establishes the system of incentives for achieving these indicators. If utilities achieve performance indicators and improve their efficiency, they increase their profits. The regulator reviews and adjusts performance indicators periodically. This form of indirect competition is effective when benchmarking methodology takes into account local conditions of the public utilities sector.

Development of new approaches to the correlation of regulation and competition result in emergence of new forms of direct and indirect competition. Application of these forms to the public utilities sector and competitive transformation of the sector expands a toolbox of the regulatory authorities and highlights their new functions.

\section{Promotion of competition in the public utilities sector}

The past decades have seen dramatic change in views how the public utilities sector should be organized and regulated in Ukraine. We agree with Yu. Vashchenko that the effectiveness of state regulation largely depends on its institutional framework. Based on the analysis of the legal status of the energy regulators, Yu. Vashchenko comes to conclusion that regulatory authorities have a special legal status that determined by the place in the system of public authorities and their functions. According to the scholar, among the core tasks of regulatory authorities are regulation of prices/tariffs for goods and ser- 
vices produced by natural monopolies, ensuring access to these goods and services, and creating conditions for the development of competition in the relevant regulated sectors (Vashchenko, 2015). Given the competitive transformation of public utilities sector in Ukraine and the expansion of the functions of regulatories authorities, development of a strong institutional framework remains a key priority for the public utilties sector.

Energy and public utilities regulator - National Commition for Energy and Public Utilities Regulation in Ukraine (hereinafter referred to as the Regulator) was established in August 2014. Two years later, the Parliament of Ukraine adopted the Law "On National Commition for Energy and Public Utilities Regulation" (Verkhovna Rada of Ukraine, 2016). The Law determines the legal status of the Regulator, its tasks, functions, powers and procedure for their performance. According to the Law, the Regulator has a special legal status of a permanently acting independent state collegial authority. Regulator performs state regulation, monitoring and control over the activity of economic entities in the sector of energy and public utilities. The key tasks of the Regulator uncludes ensuring the effective functioning and development of energy and public utilities markets, promoting effective market opening for all consumers and suppliers, and ensuring non-discriminatory access of users to networks/pipelines, as well as promoting competition in energy and utilities markets. As we see, the tasks of the Regulator reflect the latest developments in correlation of regulation and competition. The Law creates basis for promotion of competition in the public utilities in Ukraine via regulatory mechanisms, as well as expands the role of the Regulator.

Starting from 1997 public authorities developed dozens of concepts and strategies that determined a transition to competition in the public utilities sector as one of the main policy priorities. In 2017 the Cabinet of Minister of Ukraine developed new strategies for public policy in district heating, water supply and sewage, as well as waste management strategy. These strategies confirmed the intention of the government to promote competition in all industries that belong to the public utilities sector.

The Regulator may promote competition in the public utilities of Ukraine through performing monitoring over competitive segments of the market, regulation of access to networks and incentive-based regulation that includes different forms of yardstick competition.

The Law of Ukraine "On natural monopolies" (Verkhovna Rada of Ukraine, 2000) creates a legal framework for unbundling and introducing competition in the public utilities sector. The Law allocates all the activities in network industries in two groups regulated activities (natural monopoly) and activities on related markets (competitive or potentially competitive segments of the market). According to the Law, heat transmission and distribution, water supply and sewage, as well as disposal of household waste are natural monopoly activities. At the same time heat generation and supply, as well as recycling of household waste belong to potentially competitive segments of the public utilities sector. According to the legislation, natural monopoly activities should be regulated, while other activities are open for competition.

The Law creates a legal basis for separation of activities and promotion of competition in the public utilities sector. However, deregulation with structural (ownership) separation of the monopoly segments from the competitive ones is not a feasible solu- 
tion for the public utilities sector. One of the key conclusions of the World Bank Policy Research Report is that "unbundling is likely to be particularly attractive when market size and density permit many operators to function, providing both active and potential competition". Another factor required for unbundling is "a mature, well-developed set of network facilities, so there is little need for new investments in physical infrastructure" (Kessides, 2004). The benefits of competition that may come from unbundling in the public utilities sector in Ukraine will be limited because the size of markets is relatively small and the infrastructure requires substantial investments for modernization of its facilities. Concerns about structural (ownership) separation shall lead the Regulator to consider less radical alternatives and pay more attention to the access regulation.

Yardstick competition (benchmarking) has a great potential in the public utilities sector in Ukraine. Benchmarking is a part of ongoing regulatory reform in Ukraine towards transition to incentive-based regulation in the public utilities sector. In the Plan of Activities for 2018-2020, NEURC determined that the introduction of incentive-based regulation as one of the key priority. In 2017 NEURC adopted a regulatory framework for incentive-based regulation in the district heating sector, including benchmarking methodology. In 2018 NEURC plans to develop a similar regulatory framework for the sector of water supply and sewage. That means that the Regulator promotes indirect competition through regulatory mechanism.

The idea of transition to competition-based system in the public utilities sector in Ukraine is based on the assumption that the competition will create the incentives for utilities to optimize the technology of production, improve the quality of services and minimize costs and prices. However, competition will not automatically solve all the problems that sector is facing. Moreover, competitive transformation of the public utilities sector does not mean the elimination of regulation. In contrast, such transformation requires regulatory oversight of monopoly and competitive activities.

This approach strengthens the role of the Regulator, expands its core regulatory functions and allows promoting competition and achieving its benefits via regulatory instruments. That modifies the nature and scope of the Regulator's competence as the tasks of the Regulator cover regulation and monitoring. The last one takes the form of a broadly understood monitoring of the functioning of regulated sectors that includes the support of their development (including promotion of competition, energy efficiency and renewable energy, protection of customers and ensuring of secure and reliable supply).

\section{Conclusions}

Regulation and competition have the same ultimate goals - to ensure the effective market functioning. From this standpoint, we cannot consider them as exclusive mechanisms that are not able to co-exist within one market. These two mechanisms are not necessarily mutually exclusive, and neither alone can best serve the needs of most network industries that include both monopolistic and competitive segments. Based on different viewpoints it becomes apparent that in the long-term perspective a system in which regulation and competition coexist may be the best alternative for network industries.

Despite the difficulty in introducing competitive principles in the public utilities sector, some forms of direct and indirect competition occur in the sector. The separation of natural monopoly from the competitive segments of the market achieved by breaking down of 
vertically integrated monopolies and unbundling of their activities is not always feasible for the public utilities sector. Instead the forms of indirect competition such form as yardstick competition (or benchmarking) - allow achieving the benefits of competition in the public utilities sector. Introduction of competition in the public utilities sector expands a toolbox of the regulatory authorities by empowering regulators to perform monitoring over potentially competitive markets, access regulation and incentive-based regulation.

Competitive transformation of the public utilities sector of Ukraine requires effective regulatory authorities. The Regulator in Ukraine has a special legal status and responsible for promotion of competition in the public utilities sector. This mandate transforms the role of the Regulator and expend its monitoring function. However, the Regulator must strike a careful balance between its core regulatory and monitoring functions to ensure proper functioning of both mechanisms - regulatory and competitive one.

\section{Bibliography:}

1. Kovalko N., Kazantseva A. The directions of improvement of the investment attractiveness of enterprises in the sphere of municipal heat energy of Ukraine. Evropsky Politicky a Pravni Diskurz. 2015. Vol. 3. P. 225-229.

2. Дослідження чинного законодавства у сфері житлово-комунального господарства та підготовка комплексу пропозиції щодо його вдосконалення з питань надання житлово-комунальних послуг: заключний звіт / за ред. І.В. Запатріна. К., 2012. 183 с.

3. Westin P., Lagergren F. Re-regulating district heating in Sweden. Energy Policy. 2002. Vol. 30. P. 583-593.

4. Posner R.A. Natural monopoly and its regulation. Stanford Law Review. 1968. Vol. 21. P. 548-643.

5. Stigler G. Citizens and the State: essays on regulation, Chicago: University of Chicago Press, 1975. $224 \mathrm{p}$.

6. Jordana J., Levi-Faur D. The politics of regulation in the age of governance. The politics of regulation: institutions and regulatory reforms for the age of governance. Cheltenham: Edward Elgar, 2004. P. 1-28.

7. Posner R.A. Economic analysis of law. Austin: Wolters Kluwer, 2011. 1056 p.

8. Joskow P.L. Regulation and deregulation after 25 years: lessons learned for research in industrial organization. Review of Industrial Organization. 2005. Vol. 26. № 2. P. 169-193.

9. Crampton P. Striking the right balance between competition and regulation: the key is learning from our mistakes. URL: https://www.oecd.org/regreform/2503205.pdf (date of access: 21.09.2018).

10. Kessides I. Reforming Infrastructure: Privatization, Regulation, and Competition. Policy Research Report. Washington, DC: World Bank and Oxford University Press, 2004. 325 p.

11. Baldwin R., Cave M., Lodge M. Understanding Regulation: Theory, Strategy, and Practice. New York: Oxford University Press, 2012. 563 p.

12. Kirchner Ch. Regulating towards what? The concepts of competition in sector-specific regulation, the likelihood of their sustainability, and their relationship to rendering public infrastructure services. The evolution of European competition law: whose regulation, which competition? Cheltenham: Edward Elgar, 2006. P. 241-256.

13. Newbery D. Privatization, Restructuring and Regulation of Network Utilities. Cambridge, Mass.: MIT Press, 2000. 484 p.

14. Spendolini M.J. The Benchmarking Process. Compensation \& Benefits Review. 1992. Vol. 24. Issue 5. P. 21-29. 
15. Ващенко Ю.В. Адміністративно-правовий статус енергетичного регулятора в Україні: сучасний стан та перспективи реформування у контексті європейської інтеграції: монографія. К.: Юрінком Інтер, 2015. 288 с.

16. Про Національну комісію, що здійснює державне регулювання у сферах енергетики та комунальних послуг: Закон України від 22 вересня 2016 р. № 1540-VIII / Верховна Рада України. Відомості Верховної Ради України. 2016. № 51. С. 238. Ст. 833.

17. Про природні монополії: Закон України від 20 квітня 2000 р. № 1682 / Верховна Рада України. Відомості Верховної Ради України. 2000. № 30. Ст. 238.

\section{References}

1. Kovalko, N. and Kazantseva, A. (2015). The directions of improvement of the investment attractiveness of enterprises in the sphere of municipal heat energy of Ukraine. Evropsky Politicky a Pravni Diskurz, vol. 3, pp. 225-229.

2. Zapatrin I.V. (ed.) (2012). Doslidzhennia chynnoho zakonodavstva u sferi zhytlovokomunalnoho hospodarstva ta pidhotovka kompleksu propozytsii shchodo yoho vdoskonalennia z pytan nadannia zhytlovo-komunalnykh posluh: zakliuchnyi zvit [Research of the current legislation on housing and municipal economy and preparation of the complex of proposals for improvement for housing and communal services provision: final report]. Kyiv. [in Ukrainian].

3. Westin, P. and Lagergren, F. (2002). Re-regulating district heating in Sweden. Energy Policy, vol. 30, pp. 583-593.

4. Posner, R.A. (1968) Natural monopoly and its regulation. Stanford Law Review, vol. 21, pp. 548-643.

5. Stigler, G. (1975). Citizens and the State: essays on regulation. Chicago: University of Chicago Press. [in English].

6. Jordana, J. and Levi-Faur, D. (2004). The politics of regulation in the age of governance. The politics of regulation: institutions and regulatory reforms for the age of governance. Cheltenham: Edward Elgar, pp. 1-28.

7. Posner, R.A. (2011). Economic analysis of law. Austin: Wolters Kluwer. [in English].

8. Joskow, P.L. (2005). Regulation and deregulation after 25 years: lessons learned for research in industrial organization. Review of Industrial Organization, vol. 26, no 2, pp. 169-193.

9. Crampton, P. (2002). Striking the right balance between competition and regulation: the key is learning from our mistakes. Retrieved from: https://www.oecd.org/regreform/2503205.pdf.

10. Kessides, I. (2004). Reforming Infrastructure: Privatization, Regulation, and Competition. Policy Research Report. Washington, DC: World Bank and Oxford University Press. [in English].

11. Baldwin, R., Cave, M. and Lodge, M. (2012). Understanding Regulation: Theory, Strategy, and Practice. New York: Oxford University Press. [in English].

12. Kirchner, Ch. (2006). Regulating towards what? The concepts of competition in sectorspecific regulation, the likelihood of their sustainability, and their relationship to rendering public infrastructure services. The evolution of European competition law: whose regulation, which competition? Cheltenham: Edward Elgar, pp. 241-256.

13. Newbery, D. (2000). Privatization, Restructuring and Regulation of Network Utilities. Cambridge, Mass.: MIT Press. [in English].

14. Spendolini, M.J. (1992). The Benchmarking Process. Compensation \& Benefits Review, vol. 24, issue 5, pp. 21-29.

15. Vashchenko, Yu.V. (2015) Administratyvno-pravovyi status enerhetychnoho rehuliatora v Ukraini: suchasnyi stan ta perspektyvy reformuvannia u konteksti yevropeiskoi intehratsii: monohrafiia [The administrative and legal status of the energy regulator in Ukraine: the current state and prospects of the reforming in the context of the European integration: a monograph]. Kyiv: Yurinkom Inter. [in Ukrainian]. 


\title{
ОСОБЛИВЕ АДМІНІСТРАТИВНЕ ПРАВО
}

16. Verkhovna Rada of Ukraine (2016). Pro Natsionalnu komisiiu, shcho zdiisniuie derzhavne rehuliuvannia u sferakh enerhetyky ta komunalnykh posluh: Zakon Ukrainy vid 22 veresnya 2016 roku № 1540-VIII [On National Commition for Energy and Public Utilities Regulation: the Law of Ukraine dated of September 22, 2016 №1540-VIII]. Vidomosti Verkhovnoi Rady Ukrainy, no 51 , art. 833.

17. Verkhovna Rada of Ukraine (2000). Pro pryrodni monopolii: Zakon Ukrainy vid 20 kvitnya 2000 roku № 1682 [On natural monopolies: the Law of Ukraine dated of April 20, 2000 № 1682]. Vidomosti Verkhovnoi Rady Ukrainy, no 30, art. 238.

\section{РОЛЬ ОРГАНІВ ДЕРЖАВНОГО РЕГУЛЮВАННЯ В СПРИЯННІ РОЗВИТКУ КОНКУРЕНЦІЇ У СФЕРІ КОМУНАЛЬНИХ ПОСЛУГ}

\author{
Альона Казанцева, \\ учасник програми Інституту Лідерства у сфері відновлювальної енергетики, \\ м. Вашингтон \\ aokazantseva@gmail.com \\ orcid.org/0000-0003-4938-6701
}

Мета. Статтю присвячено аналізу підходів до співвідношення регулювання та конкуренції з метою визначення ролі органів державного регулювання в сприянні розвитку конкурениії у сфері комунальних послуг Украӥни.

Методи. Для иілей дослідження автор здійснює аналіз підходів до співвідночення регулювання та конкуренції, а також форм конкурениії у сфері комунальних послуг, щзо здійснюеться шляхом застосування формально-логічного й дедуктивного методів.

Результати. Перша частина статті зосереджена на аналізі теоретичних підходів до співвідношення регулювання та конкуренції в мережевих галузях. Розглядаються різні аспекти співвідношення ијих понять, а саме: дерегулювання, ре-регулювання, регулювання конкуренції, регулювання для конкурениії та мета-регулювання. Друга частина дослідження висвітлює питання щзодо форм конкуренціїу сфері комунальних послуг, у тому числі поділ вертикально інтегрованих монополій $і$ конкуренцію за показниками (бенчмаркінг). Автор розглядає декілька підходів до реструктуризації сфери комунальних послуг та ії регулювання, на підставі яких доходить висновку про те, щуо конкуренція за показниками (бенчмаркінг) має значний потенціал у сфері комунальних послуг. Третя частина публікаиії присвячена визначенню ролі органів державного регулювання в сприянні розвитку конкуренції у сфері комунальних послуг України. На підставі аналізу законодавчих актів автор доходить висновку про те, що регулятор у сфері комунальних послуг в Украйні може сприяти розвитку конкуренції шляхом здійснення моніторингу функціонування конкурентних сегментів ринку, регулювання доступу до мереж та стимулюючого регулювання, щзо включає різні форми бенчмаркінгу.

Висновки. По-перше, регулювання й конкуренція не є взаємовиключними та конкуруючими механізмами, а є такими, щзо доповнюють один одного та можуть співіснувати в межах одного ринку. По-друге, запровадження прямих і непрямих форм конкурениії у сфері комунальних послуг розширює набір регулятивних інструментів 
та, відповідно, зумовлює розширення повноважень органів державного регулювання шляхом закріплення за ними повноважень щзодо здійснення моніторингу на потенційно конкурентних ринках, регулювання доступу до мережі та стимулюючого регулювання. По-третє, регулятор у сфері енергетики й комунальних послуг в Україні здійснює забезпечення розвитку конкуренції шляхом здійснення функцій, які виходить за межі класичного розуміння регулятивних функцій, а тому неабиякого значення набуває питання збалансування функцій регулятора.

Ключові слова: регулювання, конкуренція, органи державного регулювання, мережеві галузі, сфера комунальних послуг. 